SUPPLEMENT TO THE HANDBOOK OF MIDDLE AMERICAN INDIANS

Volume 3 Literatures 
THIS PAGE INTENTIONALLY LEFT BLANK 


\section{SUPPLEMENT TO THE HANDBOOK OF MIDDLE AMERICAN}

INDIANS VICTORIA REILLR BRICKER, Geneal Editior

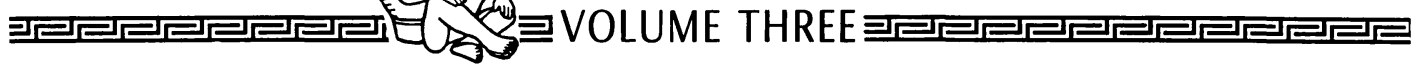

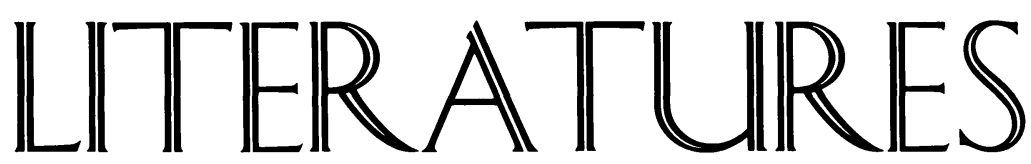

MUNRO S. EDMONSON, Volume Editor With the Assistance of Patricia A. Andrews 
Copyright (C) 1985

by the University of Texas Press

All rights reserved

Requests for permission to reproduce material from this work should be sent to:

Permissions

Box 7819

Austin, Texas 78713

LIBRARY OF CONGRESS CATALOGING

IN PUBLICATION DATA

Main entry under title:

Literatures.

(Supplement to the Handbook of Middle American Indians ; v. 3)

Bibliography: $p$.

1. Indian literature-Mexico-Addresses, essays, lectures. 2. Indian literature-Central America-Addresses, essays, lectures. I. Edmonson, Munro S. II. Andrews, Patricia A. III. Series.

PM3051.L57 $1985 \quad 897^{\prime} .4 \quad 85-3361$

ISBN 0-292-77593-8
Reprinted by permission of the Smithsonian Institution Press from Smithsonian Contributions to Anthropology, No. 19 (1975), The Great Tzotzil Dictionary of San Lorenzo Zinacantán, p. 17; No. 23 (1977), Of Cabbages and Kings, pp. 372373; No. 25 (1980), Of Shoes and Ships and Sealing Wax, pp. 208, 215-216; all by Robert Laughlin.

Grateful acknowledgment is also made to the following for permission to reprint previously published material as cited in the text: Cambridge University Press for material from Ethnography of Speaking; Harvard University Press for material from Chamulas in the World of the Sun; Instituto de Asesoría Antropológica para la Región Maya, Asociación Civil, for material from a Writers' Workshop program pamphlet; Instituto de Investigaciones Históricas for material from Tlalocan; Mouton and Co. for material from Meaning in Mayan Languages; Princeton University Library for material from the Robert Garrett Collection of Manuscripts in the Indigenous Languages of Middle America. 
To our eagles flying

One sleep ahead

Thelma D. Sullivan

FERnando Horcasitas

Alfredo Barrera Vásquez 
THIS PAGE INTENTIONALLY LEFT BLANK 